DOI https://doi.org/10.36059/978-966-397-181-0/51-66

\title{
APPARATUSES OF PUBLIC AUTHORITIES: CONCEPTS, FEATURES AND TYPES
}

\section{Hnatovska A.}

\section{INTRODUCTION}

During the period of deep transformations that covered all spheres of life of our society, its economy, politics, moral principles, the problems of improving the state apparatus providing the activity of the main links of state power acquire special significance.

The process of development ukrainian statehood, state mechanism strengthening and public administration improvement are inextricably linked to the organization and functioning of the apparatus of public authorities.

The state authorities in implimintationnof their powers, needs the assistance of competent specialists in organizational, scientific, personnel, financial, economic, legal, logistical and other support of their activities. State apparatus are created and acted upon to fulfill these tasks.

Modern conditions for the management, development and adoption of normative legal acts by state authorities require an increasing participation of subsidiary state bodies.

It is important to study the problem of systemic interaction between the legislative and executive branches of government and the functioning of the state mechanism through the prism of participation in it of the corresponding subsidiary state bodies.

Today, the emergence of managerial decisions and their implementation in regulatory acts has been little researched. Only few scientists describe the functioning of those bodies that facilitate the work of state bodies of all branches of government, ensure their interaction and cooperation with each other.

\section{Legal research variety of subsidiary bodies titles}

In Ukraine, such subsidiary bodies have different names, such as: secretariats, administrations, offices. In addition, their names change periodically with the change in political power that comes to power. Therefore, before proceeding directly to the analysis of the activity of the said bodies, we want to dwell on the definitions of the said concepts.

The term "administration" in the legal dictionary of 1956 is defined as the heads of enterprises, institutions or organizations, which are obliged 
within the limits of the rights and duties assigned to them to manage the assigned work area ${ }^{1}$.

The Legal Encyclopedic Dictionary of 1987 defines the administration as a state body that performs executive-administrative activity, ensures the implementation of laws and other decisions of legislative bodies on a national scale or within the scope of a separate sphere of public administration ${ }^{2}$.

The Legal Encyclopedia of 2003 gives the following definitions of administration - an institution that performs management functions in various spheres of public life. There are several aspects to using the term "administration":

1) in the phrase "public administration" is sometimes used to define the system of executive bodies;

2) the name of the specific executive bodies of administrative-territorial units in Ukraine;

3) with the introduction of the presidency institute in Ukraine, a working apparatus of the head of state was created, called the Administration of the President of Ukraine;

4) the most common name of the governing body of an enterprise, institution, organization ${ }^{3}$.

Thus, the term "administration" has been inextricably linked to the exercise of managerial functions since the 1950s.

In Ukraine, to ensure the effective implementation of its constitutional powers, the realization of a consolidating role for the unification of all constructive forces in society, accelerated resolution of urgent social, economic and other problems, reduction of expenditures of the State budget, in accordance with Article 106, paragraph 28, of the Constitution of Ukraine, the Presidential Administration of Ukraine operates ${ }^{4}$.

It should be noted that the name of the apparatus of the President of Ukraine changed periodically. Only in the last 10 years has this body been reorganized by the Decree of the President of Ukraine from January 24, 2005 from the Administration of the President of Ukraine to the Secretariat of the President of Ukraine 5 . Further, to confirm this, by the Decree of the

1 Юридический словарь : у 2 т. / П.И. Кудрявцев. М : .Государственное издательство юридической литературы, 1956. Т. 1. 688 с. С. 22.

2 Юридический энциклопедический словарь / А.Я. Сухарев. М. : Сов. энциклопедия, 1987. 528 с. С. 19.

${ }^{3}$ Юридична енциклопедія: в 6 т. / Ю.С. Шемшученко. К. : Укр. енцикл., 2003. URL: http://leksika.com.ua/16930528/legal/administratsiya.

${ }^{4}$ Про першочергові заходи із забезпечення діяльності Президента України : Указ Президента України від 25.02.2010 p. № 265/2010 URL: http://zakon.nau.ua/doc/ ?doc_id=533672.

${ }^{5}$ Про Секретаріат Президента України : Указ Президента України від 24.01.2005 p. № 108/2005 URL: http://zakon.nau.ua/doc/?doc_id=469993 
President of Ukraine of 14.10.2005 No. 1445/2005 "On the creation of the Secretariat of the President of Ukraine" in accordance with paragraph 28 of the first article of Article 106 of the Constitution of Ukraine it was decided to create the Secretariat of the President of Ukraine as an helper body to ensure that the President of Ukraine implements his powers ${ }^{6}$.

Presidential Decree No. 265/2010 of February 25, 2010 "On Priority Measures to Ensure the President of Ukraine's Activities" The Secretariat of the President of Ukraine was abolished and formed the Presidential Administration of Ukraine, which was entrusted with the organizational, legal, advisory, logistical and other support for the implement of constitutional powers by the head of state ${ }^{7}$.

While the authority of this body did not actually change, they were constantly exercised regarding:

- organizational support;

- preparation of speeches of the President;

- organization of observance of the State Protocol and Ceremonial; staffing;

- state legal support; documentary support;

- domestic policy and regional development;

- issues of international cooperation; security and defense policy;

- the activities of law enforcement agencies;

- socio-economic development;

- humanitarian development issues;

- information policy;

- ensuring relations with the Verkhovna Rada of Ukraine and the Cabinet of Ministers of Ukraine;

- analysis and prompt response;

- work with citizens' appeals;

- conferring state awards and heraldry;

- citizenship issues;

- questions of pardon;

- ensuring relations with the Constitutional Court of Ukraine;

- ensuring communication with the Verkhovna Rada of Ukraine;

- ensuring communication with the Cabinet of Ministers of Ukraine;

- control and regime-secret activity.

What is the meaning of changing the name of the Presidential Office to the secretariat or administration?

${ }^{6}$ Про створення Секретаріату Президента України : Указ Президента України від 14.10.2005 p. № 1445/2005 URL: http://zakon.nau.ua/doc/?code=1445/2005

${ }^{7}$ Про першочергові заходи із забезпечення діяльності Президента України : Указ Президента України від 25.02.2010 p. № 265/2010 URL: http://zakon.nau.ua/doc/? doc_id $=533672$ 
After all, the actual powers of the body remained unchanged, its structure and civil servants holding managerial positions in the body partly changed, and the actual auxiliary character of the activity of this body remained unchanged ${ }^{8}$.

The term "secretariat" (late Latin secretariatum - the office of the secretary) is defined as an elected body or administrative department in an institution, organization, conference, congress, which directs the current work or performs organizational and technical functions, or as a set of employees of such body, department ${ }^{9}$.

We begin to analyze the activity of the executive bodies apparatuses. And let's start with the regulatory definition according to which the apparatus of the executive authorities - it is an organizationally combined set of structural units and positions, which are intended to perform advisory or service functions for the performance of the respective powers (competences) assigned to them by the respective bodies. The civil servants and other employees of the apparatus are the personnel of the executive branch.

Such a definition of the apparatus of the executive authorities in section 7 is laid down in Presidential Decree No 810/98 of 22 July 1998 "On Measures to Implement the Concept of Administrative Reform in Ukraine" 10 .

In order to ensure the fullest and most accurate implementation of the constitutional status of the Cabinet of Ministers as the supreme body in the system of executive bodies of Ukraine, the Cabinet of Ministers should become a center of public administration, the effectiveness of which is based on the support of the Parliament and the President of Ukraine. He shall be responsible to the President of Ukraine, under the control and accountability of the Verkhovna Rada of Ukraine within the limits provided for in Articles 85 and 87 of the Constitution of Ukraine ${ }^{11}$.

8 Гнатовська А.І. Історичний аналіз правового регулювання діяльності Адміністрації Президента України / А.І. Гнатовська Вісник Чернівецького факультету Наиіонального університету “Одеська юридична академія” : збірник наукових статей. Чернівці, 2014. № 4. С. 48-50.

${ }^{9}$ Юридична енциклопедія: в 6 т. / Ю.С. Шемшученко. К. : Укр. енцикл., 2003. URL : http://leksika.com.ua/16930528/legal/administratsiya.

${ }^{10}$ Про заходи щодо впровадження Концепції адміністративної реформи в Україні : Указ Президента України від 22 липня 1998 р. № 810/98 URL: http://zakon.nau.ua/doc/? uid $=1082.2758 .7 \&$ nobreak $=1$

${ }^{11}$ Конституція України : Закон України від 28.06.1996р. 254к/96-ВР Відомості Верховної Ради Украӥни, 1996, № 30, ст. 141. 
An important condition for the realization of the constitutional status of the Cabinet of Ministers is to ensure a harmonious relationship between the Government and the Presidential Administration.

It is appropriate to establish by law that officials of the Cabinet of Ministers are involved in the relations of the Cabinet of Ministers services with the Presidential Administration, advisory, advisory and other subsidiary bodies and services established by the President.

In addition, the Concept of Administrative Reform in Ukraine states that changes in the organization of work of the Cabinet of Ministers necessitate the reorganization of its apparatus, the task of which should be, inter alia, organizational, information-analytical, legal, logistical and other services of the Cabinet of Ministers, governmental committees.

The Cabinet of Ministers apparatus is proposed to be called the Secretariat of the Cabinet of Ministers, which is more in line with the tasks and functions assigned to it.

The Secretariat of the Cabinet of Ministers ensures the creation of conditions for the collective work of the Cabinet of Ministers as a whole and of governmental committees as well as ministers as members of the Cabinet of Ministers. The Secretariat does not instruct ministers, and its work does not replace the activities of ministers as members of government.

Cabinet of Ministers Secretariat:

a) assists the Prime Minister and the Deputy Prime Ministers in organizing the work of the Government;

b) inform relevant ministries of documents submitted to the Cabinet of Ministers and governmental committees;

c) ensure that the decisions of the Cabinet of Ministers and governmental committees are documented, these decisions are forwarded to the ministers and the government receives information on their implementation;

d) supervise the implementation of decisions of the Cabinet of Ministers;

e) provide expert opinions to the Prime Minister and Vice Prime Ministers on sectoral (sectoral) politics;

f) provide organizational support to the meeting of governmental committees (councils);

g) liaise with the Secretariat of the Verkhovna Rada and the Presidential Administration and inform the Presidential Administration of the decision of the Cabinet of Ministers;

h) provide legal expertise of draft decisions of the Cabinet of Ministers and other legislative acts. 
According to Part 10 of Art. 48 of the Law of Ukraine "On the Cabinet of Ministers of Ukraine"12 and the Concept of Administrative Reform in Ukraine 12.08.2009 by Resolution No. 850 the Cabinet of Ministers of Ukraine approved the Regulation on the Secretariat of the Cabinet of Ministers of Ukraine ${ }^{13}$.

This Regulation defines the Secretariat of the Cabinet of Ministers of Ukraine as a permanent body providing its activities and fulfilling the tasks of organizational, expert-analytical, legal, informational, logistical support of the Government's activity.

In its activities, the Secretariat cooperates in due course with the Presidential Administration of Ukraine, the Verkhovna Rada of Ukraine, the apparatus of the National Security and Defense Council of Ukraine, the ministries and other central executive bodies, the Council of Ministers of the Autonomous Republic of Crimea, oblast, Kyiv and Sevastopol state administrations, bodies, bodies of local self-government and their officials, associations of citizens, enterprises, institutions and organizations.

We draw your attention to the fact that item 9 of the Regulation states that in order to ensure the exercise of the Prime Minister of Ukraine of his powers within the Secretariat, the Office of the Prime Minister of Ukraine is formed, whose head is appointed and dismissed by the Cabinet in due course. Ministers of Ukraine upon the submission of the Prime Minister of Ukraine. That is, the Prime Minister's Office operates within the Secretariat of the Cabinet of Ministers of Ukraine.

Thus, the activity of the apparatus of the Cabinet of Ministers of Ukraine is not limited to organizational activities or the implementation of logistical operations, therefore, we believe that the concept of "secretariat" does not reveal the full content of the activity of the apparatus of a higher executive body. Such a name restricts its activities solely to the exercise of organizational and logistical functions, which is absolutely not consistent with the validity of its legal status.

The definition of the term "apparatus" (from Latin apparatus equipment) is given as an institution or a set of institutions serving a particular branch of management, economy or as a set of employees of the institution (organization), its staff ${ }^{14}$.

12 Про Кабінет Міністрів України : Закон України від 27 лютого 2014 року № № 794-VII URL: https://zakon.rada.gov.ua/laws/show/794-18.

${ }^{13}$ Положення про Секретаріат Кабінету Міністрів України : Постанова Кабінету Міністрів України від 12 серпня 2009 р. N 850 URL: https://zakon.rada.gov.ua/laws/show/ 850-2009-\%D0\%BF.

${ }^{14}$ Українська радянська енциклопедія URL: http://leksika.com.ua/19430110/ure/aparat 
Considering the auxiliary nature of the activities of bodies that contribute to the operation of the entire state mechanism, we believe that among the above concepts, the most appropriate is the "apparatus".

In support of this we give the opinion of V.B. Averyanov, who defines the organ of the body as an organizational entity whose main purpose is to create all the necessary conditions for the effective exercise of the powers conferred on him by the body, although in itself the "apparatus" performs certain power and administrative actions that have exclusively internal organizational orientation and character ${ }^{15}$.

To confirm this view, let us turn to the characteristics of the activity of the Verkhovna Rada of Ukraine Apparatus, which ensures the functioning of the legislative branch of power.

This body carries out legal, scientific, organizational, documentary, informational, personnel, financial and economic, logistical, social and other supporting activity of the Verkhovna $\operatorname{Rada}^{16}$. The legal status of the apparatus of the Verkhovna Rada of Ukraine is determined by the Principle on the Apparatus of the Verkhovna Rada of Ukraine approved by the Prescript of the Chairman of The Verkhovna Rada of Ukraine No. 769 of 25.08.2011.

The structure of the Verkhovna Rada's apparatus consists of secretariats, departments, departments and the Legislation institute of the Verkhovna Rada.

All these units are working to improve the work of Parliament, get it better and develope the quality of its work.

The apparatus of the Verkhovna Rada of Ukraine provides various directions of parliament activities. Properly organized work of the apparatus of the Verkhovna Rada of Ukraine is the key to effective implementation of their powers by the Verkhovna Rada of Ukraine and the Deputies of Ukraine, as well as the adoption and control over the implementation of normative and individual legal acts ${ }^{17}$.

Among the functions of the apparatus of the Verkhovna Rada of Ukraine aimed at ensuring quality cooperation of the Parliament with other branches of government are the following:

15 Авер'янов Вадим Борисович. Вибрані наукові праці / Ю.С. Шемшученко, О.Ф. Андрійко. К. : Інститут держави і права ім. В.М. Корецького НАН України, 2011. 488 c. C. 159.

16 Положення про Апарат Верховної Ради України : Розпорядження Голови Верховної Ради України від 25.08.2011 р. № 850 URL : http://zakon.nau.ua/doc/?code=769/ $11-\% \mathrm{D} 0 \% \mathrm{C} 3$

${ }^{17}$ Колодій А.М., Олійник А.Ю. Державне будівництво і місцеве самоврядування в Україні: підручник. К. : ЮрінкомІнтер, 2007. 504 с. С. 114-115. 
1) facilitating cooperation on the legislative work of committees of the Verkhovna Rada, parliamentary factions and groups with the Administration of the President of Ukraine, the Cabinet of Ministers of Ukraine, ministries, other central executive bodies, scientific and public organizations, local selfgovernment bodies;

2) interaction with the executive authorities, local self-government bodies in preparation of issues submitted to the Verkhovna Rada of Ukraine, its committees;

3) participation in the organization of control over the implementation of laws and other acts of the Verkhovna Rada of Ukraine and its bodies;

4) organization of control over the observance of the terms of consideration of requests of the Deputies and execution of orders contained in the acts of the Verkhovna Rada of Ukraine by the Cabinet of Ministers of Ukraine, ministries and departments, etc. ${ }^{18}$

The content activity of the apparatus of the Verkhovna Rada of Ukraine is that this body carrying out all the "draft" work of the Parliament, helps the deputies to implement qualified legislative activity without burdening with organizational and logistical issues.

Ukrainian deputies is objectively unable to have specific knowledge of all spheres of public life, so during passing laws they receive professional help from the apparatus of the Verkhovna Rada of Ukraine, which consists of qualified specialists of different profiles.

That is, the apparatus of the Verkhovna Rada of Ukraine creates the necessary favorable conditions for the deputies of the Verkhovna Rada of Ukraine to adopt grounded, qualitative and effective norms.

Having conducted a general theoretical analysis of the activity of the apparatus of the higher bodies of state power, we come to the conclusion that such use of terms in regulatory legal acts is not very appropriate. Secretariat covers only activities related to organizational and technical support and paperwork, while the functions of the Secretariat of the Cabinet of Ministers of Ukraine also include legal, scientific, expert, analytical activity, which is more characteristic of the apparatus of the state authority.

Moreover, the term "apparatus" is broader and more capacious in terms of its functions, which is why the secretariat cannot include an official's apparatus in its structure.

That is why, it would be appropriate to change the name of the Cabinet of Ministers of Ukraine to the Apparatus of Ministers of Ukraine.

18 Адміністративне право України. Академічний курс : підручник : у 2 т. Т. 1. Загальна частина / ред. колегія: В.Б. Авер'янов (голова) та ін. К. : Вид-во “Юридична думка", 2004. С. 231-232. 


\section{The features and types of public authorities apparatus}

Having justified the expediency of using the term "apparatus" in the name of a body which directs its activities to the assistance and support of the work of public authorities, we proceed to determining the features of the apparatus of public authorities. But before that, we consider it necessary to determine the difference between the apparatus and the state authorities.

The apparatus of a public authority belongs to the system of public authorities, but its legal status should be distinguished from the legal status of public authorities. To do this, let us define what a public authority is and how the apparatus of a public authority differs from it.

It is necessary to distinguish between public authorities in their competence, which includes the powers of public authorities and their functions.

The functions of public authorities determine the scope of their activity, and the powers determine what actions these functions are implemented. The functions and powers of the apparatus of the bodies of state power depend on the competence of the bodies at which they are created.

Quite often, the activity of the apparatus of public authorities is expressed in regulatory acts adopted by the public authority. Thus, the President of Ukraine often reflects in his decrees the work of his administration. That is, the implementation of the work and decision of the apparatus occurs through a regulatory act of the body of work which he promotes.

The legal status apparatus of public administration bodies differs significantly from the legal status of public authorities in that they do not have state powers and are not responsible for the consequences of their activities.

Let us distinguish the following differences between the apparatus of public authorities and state-governmental entities:

- Apparatuses of public authorities differ from public authorities in the order of their creation and formation;

- the internal organization of the apparatus of a public authority depends on the state-power entity to which it acts;

- the result of apparatus activity of a public authority cannot be stategovernment decisions or normative-legal acts

- apparatus of public authorities are accountable to the public authority which they operate, but not to the state.

Apparatus of state bodies carrying out auxiliary functions act under different state-governmental entities, each of them with the basis for activity has its own legal act, its structure and so on. 
In this regard, we distinguish the types of apparatus of public authorities by the criteria:

1. By scope:

- apparatus of public authorities of general competence are bodies whose activity is aimed at ensuring the realization of all the basic powers of a public authority;

- apparatus of public authorities of special competence are bodies whose activity is aimed at providing certain spheres of activity of the body of a public authority.

2. By structure:

- the apparatuses employees of which are the officials, whose duty is to ensure the activity of the public authority under which they are established;

- the apparatuses employees of which are the officials, which have their own powers for which the provision of the activities of public authorities is an additional activity.

3. By the structure of public authority:

- apparatus of collegial bodies - of the Verkhovna Rada of Ukraine, of the Cabinet of Ministers of Ukraine, etc .;

- apparatus of single bodies (single state government entities) Administration of the President of Ukraine, personal assistants (referents) and secretaries of parliamentarians, etc.

The apparatus of the collegial bodies may have a vertical structure in which the units established under bodies with a large scope of competence are superior to the units of bodies with a smaller scope of competence. The secretariat of the chamber is considered to be the highest in relation to the secretariats of committees. There may not be a hierarchical relationship between such units, but the coordinating function of the secretariats of committees is inevitably exercised by the secretariat of the chamber.

Personal assistants and secretaries lock in on their parliamentarian and work autonomously. He himself defines their tasks and functions.

In fact, it is the apparatus of the public authority that ensures the quality and professionalism of its work (especially with regard to the apparatus of parliament).

In addressing the ancillary issues, the apparatus enables the public authority to focus on the skilled exercise of its public authority functions. Nowadays, no one is able to be equally aware in all spheres of society, so the apparatus of the state authority with professional and qualified specialists of different profiles comes to the rescue.

The purpose of the apparatus is to assist the official or public authority to obtain all possible information on an urgent matter that will help to formulate an objective position adequate to the situation in order to resolve a particular issue. 
Public authorities require maintenance, so organizational and technical functions (information gathering, communication support, correspondence, organization and documentation, accounting, etc.) are important elements of the apparatus.

The considerable amount of stored and updated information allows these institutions to carry out serious research on the most important problems of economy, legislation, public service, provide quality expert assessments and provide parliamentarians with independent information.

An important area of activity of the apparatus of the public authority is to maintain relations with other public authorities and officials. For example, the legislative and executive branches of power act each in their own sphere and therefore have their own specific interests, between them inevitably there are contradictions, lack of understanding, which, in turn, entails ignorance of the other party's intentions, distrust, desire to counteract. There is inconsistency in actions and even discrepancies in terminology.

Helping the government find out the legislator's intentions, facilitating a co-ordination of the approaches of the two branches of government to the problem are often resolved by an auxiliary apparatus: by the Secretariat of the Cabinet of Ministers of Ukraine and the apparatus of the Verkhovna Rada of Ukraine ${ }^{19}$.

Such contacts between state authorities are the basis and preparation for political cooperation between the Cabinet of Ministers of Ukraine and parliamentary committees.

Apparatuses of both branches of power are connecting bodies that help to reconcile issues of joint competence in the early stages of work, which undoubtedly contributes to the reduction of conflicts and differences of opinion at the level of state-governmental entities.

In addition to the fact that the bodies of state authorities facilitate the work of their bodies with other entities, they contribute to the exercise of control and supervisory functions of the body over other entities. The device collects the necessary information, analyzes it and gives conclusions about it.

The apparatus promotes the interaction of the body not only with other state-governmental entities, but also establishes contacts with public organizations, entrepreneurs, trade unions and other groups of society.

Contacts with the media are important: organizing interviews, press conferences and briefings with the government and their officials. For this purpose, special departments - press services are created in the apparatus, as well as special assistants of deputies, ministers and officials.

19 Tamara Latkovska, Lyubov Bila-Tiunova Political and economic governance: a comparative analysis of Eastern European countries and Ukraine. Baltic Journal of Economic Studies. Volume 5 Number 3. Riga: Publishing House "Baltija Publishing". 2019. P. 94. 
The content of the activity of the apparatus of the state authorities is of a "provisional" nature, that is, they are aimed at supplementing the statepower powers of the body under which the apparatus operates. The said "provisional" powers of the apparatus of the state authority are manifested in the fact that they exist for the implementation of the decisions of the stategovernmental entity, with the help of which it influences the state authorities and the society in pursuit of its purpose.

The apparatus of officials of public authorities, as a rule, is made up of persons who are close to an official of one or another circumstances to whom he may entrust the execution of his duties and the exercise of his powers, unlike professional civil servants.

Apparatuses of public authorities carry out an important function of mediation between the body with which they are created and operate, and other public authorities. They shall fully inform the Authority of any external circumstances that are relevant to the Authority's activities in the making of its competence.

Apparatuses of public authorities have a wealth of information that enables them to influence all kinds of relationships in the legal, administrative, business or other fields. Thus, the apparatus of public authorities have significant leverage on the external relations of the public authority.

They can use this situation to their advantage and do not always perform their functions as envisaged by the state authority, so it is important to carry out a number of control and monitoring measures to check the quality of its activity in order to prevent abuse of the state authority's apparatus.

The peculiarity of the powers of state bodies apparatuses is that they often perform not only those powers enshrined in a normative legal act that enshrines their legal status, but also powers that are not spelled out but due to the nature of the close interconnection of the organ and its apparatus. This is especially true for apparatus operating with an official who completely trusts his assistants and gives tasks that do not always correspond to those stipulated in the legal act.

There is no common approach to identifying characteristics of public authorities that exercise ancillary functions. States have different names, different order of establishment and different legal status for apparatuses. This situation leads to the absence of common scientific views on the issue of determining the legal status of the apparatus of public authorities and does not allow to develop the basic principles of their activity. But after learning the content of the activity of the apparatus of public authorities and highlighting their differences from the public authorities, we can identify the following features of the apparatus of the public authority: 
- the apparatus is created and operates in the manner determined by the normative legal acts (both by laws and by-laws);

- the apparatus does not have managerial functions, but implement the authority of the body under which it operates;

- the purpose of the apparatus is to promote and support the work of a state authority or official;

- the apparatus has the status of a public authority;

- acceptance, passage and termination of service in the apparatus of the authority depends on the official or the body at which the apparatus operates;

- the apparatus does not bear legal responsibility for the exercise of its powers before the state, but only before the state-governmental entity for the benefit of which it carries out its activities.

Therefore, each branch of government has its subsidiary bodies, which differ in their structure, scope of competence and field of activity.

However, for each of them the functions such as organizational, informational, scientific, personnel, financial, logistical, legal, documentary support of the activity of the state authority are common. Therefore, in order to avoid confusion in defining the names of such bodies and taking into account their common functions defined in regulatory legal acts, we consider the term "apparatus of a public authority" to be most relevant.

\section{CONCLUSIONS}

Each branch of government has its subsidiary bodies, which differ in structure, scope of competence and field of activity. However, for each of them the functions such as organizational, informational, scientific, personnel, financial, logistical, legal, documentary support of the activity of the state authority are common. Therefore, in order to avoid confusion in defining the names of such bodies and taking into account their common functions defined in regulatory legal acts, we consider the term "apparatus of a public authority" to be most relevant and relevant.

The apparatus of a public authority ensures the activity of all public authorities. The apparatus of state authority directly carry out all the "draft" work to ensure the solution of problems. Due to the fact that they are entrusted with the functions of facilitating the work of such bodies as the Verkhovna Rada of Ukraine, the President of Ukraine, the Cabinet of Ministers of Ukraine, etc. the bodies under study are active participants in the implementation of tasks and functions of state power.

Public authorities have state-power powers to adopt normative legal acts, make legally significant decisions, and regulate public relations. Apparatuses of public authorities direct their activities to ensure the implement of powers of public authorities. For this purpose the apparatus carry out many auxiliary 
and support functions, the purpose of each of which is to promote the work of the authority and to provide high-quality, scientifically substantiated and technically supported work of the state authority.

The legal status of the apparatus depends entirely on the status of the body with which it operates, but due to the diversity of its activities, the apparatus has a much wider range of information about the state of affairs, which gives it the opportunity to influence the work of a public authority, which is not always correct and appropriate.

Having conducted a study of the activity of the apparatus of public authorities, defining their types and features, we establish that the apparatus of the public authority is a public authority that functions in accordance with the procedure established by law to ensure the activity of a stategovernmental entity within the powers assigned to it for the purpose of securing and promoting its activities.

\section{SUMMARY}

The article is devoted to the study of the concepts of "apparatus", "secretariat" and "administration" of a public authority. The outlined concepts are investigated in legal encyclopedias, in the works of domestic scientists and in the normative legal acts of Ukraine. We described the advisability of using the definition - staff by the researching of legal norms which govern the working of The Verkhovna Rada of Ukraine Secretariate, Presidential Administration and Cabinet of Ministers of Ukraine Secretariate.

The article explores the powers of the auxiliary bodies of state power. Priority directions of work of state authorities' apparatus are determined.

By means of systematic analysis, common features of the apparatus of public authorities are identified.

The article proposes the criteria for division of apparatus of state authorities: by the scope of the apparatus, by the composition of the apparatus, by the structure of the body at which the apparatus operates.

\section{REFERENCES}

1. Юридический словарь : у 2 т. / П.И. Кудрявцев. М : .Государственное издательство юридической литературы, 1956. Т. 1. $688 \mathrm{c}$.

2. Юридический энциклопедический словарь / А.Я. Сухарев. М. : Сов. энциклопедия, 1987.528 с.

3. Юридична енциклопедія: в 6 т. / Ю.С. Шемшученко. К. : Укр. енцикл., 2003. URL: http://leksika.com.ua/16930528/legal/administratsiya. 
4. Про першочергові заходи із забезпечення діяльності Президента України : Указ Президента України від 25.02.2010 р. № 265/2010 URL: http://zakon.nau.ua/doc/?doc_id=533672.

5. Про Секретаріат Президента України : Указ Президента України від 24.01.2005 р. № 108/2005 URL: http://zakon.nau.ua/doc/?doc_id= 469993.

6. Про створення Секретаріату Президента України : Указ Президента України від 14.10.2005 p. № 1445/2005 URL: http://zakon.nau.ua/doc/?code=1445/2005.

7. Про першочергові заходи із забезпечення діяльності Президента України : Указ Президента України від 25.02.2010 р. № 265/2010 URL: http://zakon.nau.ua/doc/?doc_id=533672.

8. Гнатовська А.І. Історичний аналіз правового регулювання діяльності Адміністрації Президента України / А.І. Гнатовська Вісник Чернівецького факультету Національного університету “Одеська юридична академія" : збірник наукових статей. Чернівці, 2014. № 4. C. $47-56$.

9. Юридична енциклопедія: в 6 т. / Ю.С. Шемшученко. К. : Укр. енцикл., 2003. URL: http://leksika.com.ua/16930528/legal/administratsiya.

10. Про заходи щодо впровадження Концепції адміністративної реформи в Україні : Указ Президента України від 22 липня 1998 р. № 810/98 URL: http://zakon.nau.ua/doc/?uid=1082.2758.7\&nobreak=1.

11. Конституція України : Закон України від 28.06.1996р. 254к/96ВР Відомості Верховної Ради України, 1996, № 30, ст. 141.

12. Про Кабінет Міністрів України : Закон України від 27 лютого 2014 року № № 794-VII URL: https://zakon.rada.gov.ua/laws/show/794-18.

13. Положення про Секретаріат Кабінету Міністрів України : Постанова Кабінету Міністрів України від 12 серпня 2009 р. N 850 URL: https://zakon.rada.gov.ua/laws/show/850-2009-\%D0\%BF.

14. Українська радянська енциклопедія URL: http://leksika.com.ua/ 19430110/ure/aparat.

15. Авер'янов Вадим Борисович. Вибрані наукові праці / Ю.С. Шемшученко, О.Ф. Андрійко. К. : Інститут держави і права ім. В.М. Корецького НАН України, 2011. 488 с.

16. Положення про Апарат Верховної Ради України : Розпорядження Голови Верховної Ради України від 25.08.2011 р. № 850 URL: http://zakon.nau.ua/doc/?code=769/11-\%D0\%C3.

17. Колодій А.М., Олійник А.Ю. Державне будівництво і місцеве самоврядування в Україні: підручник. К. : ЮрінкомІнтер, 2007. 504 с. 
18. Адміністративне право України. Академічний курс : підручник : у 2 т. Т.1. Загальна частина / ред. колегія: В.Б. Авер'янов (голова) та ін. К. : Вид-во "Юридична думка", 2004. 584 с. С. 231-232.

19. Tamara Latkovska, Lyubov Bila-Tiunova Political and economic governance: a comparative analysis of Eastern European countries and Ukraine. Baltic Journal of Economic Studies. Volume 5 Number 3. Riga: Publishing House "Baltija Publishing". 2019. P. 91-98.

\section{Information about the author:} Hnatovska A., Candidate of JuridicalSciences, Associate Professor, Senior Lecturer at the Department of Constitutional, Administrative and Finance Law, Chernivtsi Law Institute, National University "Odessa Law Academy" 7, Skovorody str., Chernivtsi, 58000, Ukraine ORCID ID: orcid.org/0000-0001-7171-3209 